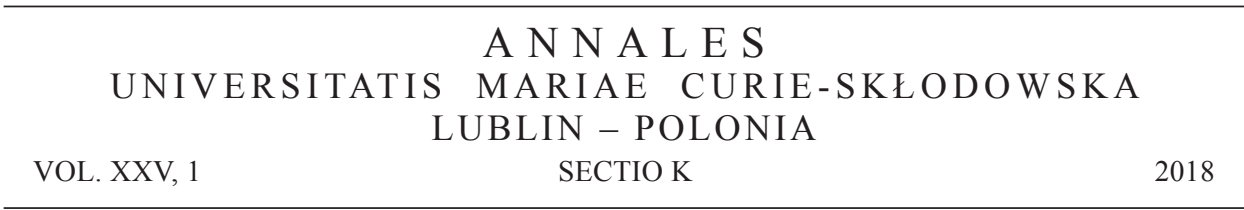

Instytut Socjologii i Kognitywistyki Uniwersytetu w Białymstoku

\title{
SŁAWOMIR BARTNICKI
}

\section{Uwarunkowania szans wyborczych ubiegających się o reelekcję wójtów i burmistrzów w wyborach $w 2014$ roku ${ }^{1}$}

Determinants of the Electoral Chances of Rural Commune Heads and Town Mayors

Running for Re-election in 2014

\begin{abstract}
ABSTRAKT
Celem analizy było określenie wpływu kwantyfikowalnych cech charakteryzujących kandydatów i gminy (zmienne niezależne) na szanse reelekcji wójtów i burmistrzów w wyborach konkurencyjnych rozgrywanych w regulaminowym terminie w 2014 roku (zmienna zależna). Przyjęto, że szanse reelekcji wójtów i burmistrzów w wyborach w 2014 roku warunkował zestaw wybranych 15 zmiennych objaśniających, takich jak m.in.: staż na stanowisku, posiadanie większości w radzie gminy z wyborów poprzednich, wydatki majątkowe inwestycyjne per capita w roku wyborczym. Zmienne niezależne pochodzą głównie ze źródeł statystyki publicznej (np.: GUS, PKW) i są dobierane na podstawie wskazań literatury przedmiotu i wniosków z badania terenowego. Do weryfikacji założeń wykorzystano regresję logistyczną zastosowaną na próbie dobieranej spośród wszystkich gmin poza miastami na prawach powiatu, równoważącej proporcję porażek i sukcesów wyborczych w 2014 roku.

Wyniki analizy sugerują między innymi, że szanse ponownego wyboru w 2014 roku wzrastały w przypadku: rządzenia od 2010 roku, a nie dłużej, posiadania większości w radzie gminy według stanu formalnego z wyborów poprzednich czy wyższego wydatkowania inwestycyjnego w roku wyborczym. Szanse reelekcji zmniejszały się z kolei wraz ze wzrostem między innymi: konkurencji wyborczej czy udziału wydatków na pomoc społeczną w ogólnej puli wydatków gmin w roku wyborczym.
\end{abstract}

Słowa kluczowe: wójt, burmistrz, czynniki reelekcji, wybory w 2014 roku

1 Artyku jest efektem grantu Narodowego Centrum Nauki (2014/13/D/HS5/02010) pt. „Uwarunkowania reelekcji egzekutywy gminnej po 2002 roku w Polsce". 


\section{WSTĘP}

Problematyka bezpośredniego wyłaniania wójtów, burmistrzów i prezydentów miast przeżywa obecnie swój renesans w dyskursie publicznym (czy ograniczać, w jakim formacie i od kiedy kadencję dla kierowników gminnej egzekutywy) oraz w analizach naukowych [np. Bober i in. 2013; Drzonek 2013]. Szczególnie wielokadencyjnych wójtów i burmistrzów w gminach o małej liczbie ludności i peryferyjnie położonych podejrzewa się o uwikłanie w relacje klientelistyczne, które mają pomagać czy wręcz gwarantować pozostawanie na stanowisku [np. Bober i in. 2013]. Argument ten wydaje się być głównym powodem rosnącego zainteresowania dynamiką rządzącą tymi wyborami. Jednocześnie schemat wyłaniania organu wykonawczego gmin w głosowaniu bezpośrednim w trybie wyborów większościowych (okręg wyborczy to gmina) stwarza możliwości względnie obiektywnej analizy uwarunkowań reelekcji wśród zajmujących te stanowiska. Dlatego celem przedkładanego artykułu jest określenie: w jakim stopniu i jakie czynniki charakteryzujące gminy i kandydatów (zmienne niezależne), spośród sugerowanych, moderowały szanse reelekcji wójtów i burmistrzów w wyborach konkurencyjnych i rozgrywanych w trybie regulaminowym w 2014 roku. Z analizy wykluczono miasta na prawach powiatu. Założono, że wielozakresowe różnice cech miast na prawach powiatu są na tyle duże, że będą efektywnie zakłócać predykcję modeli statystycznych, i gminy te należy traktować jako osobny zbiór do analizy. Poza tym jednostek tych jest względnie niewiele w populacji generalnej gmin w Polsce.

Kolejna część artykułu przedstawia teoretyczne i empiryczne wyjaśnienia uwarunkowań reelekcji i zjawiska incumbency advantage wraz z uzasadnieniem jego zmiennej dynamiki w zakresie ludnościowej wielkości gmin. Następnie przedstawiono założenia analizy, charakterystykę bazy danych i metodologię. W dalszej kolejności - przyjmowane założenia oraz ich weryfikację. Artykuł kończy analiza i wnioski.

\section{PRZYCZYNY REELEKCJI}

Wśród przyczyn utrzymywania się na stanowisku osoby wyłanianej w bezpośrednich i demokratycznych wyborach literatura światowa w pierwszej kolejności wskazuje rentę z tytułu sprawowania władzy (tzw. incumbency advantage). Ubiegających się o reelekcję określa się mianem inkumbentów, i to właśnie oni mają mieć największe szanse na sukces wyborczy bez względu na to, czy chodzi o wybory lokalne [np. Trounstine 2011; Freier 2015; Oliver, Ha, Callen 2012] czy centralne [Gelman, King 1990; Stonecash 2008; Lee 2001, 2008]. Literatura w tym zakresie jest dość ekstensywna i potwierdza, że status inkumbenta jest najsilniejszym predyktorem reelekcji. Od tej zasady odnajdujemy tylko nieliczne wyjątki (tzw. incumbency disadvantage), które można tłumaczyć silną delegitymizacją władzy o podłożu ekonomicznym [np. Titiunik 2011; Uppal 2009; Macdonald 2014]. 
Dominacja inkumbentów w wyborach wynika z kilku czynników. Po pierwsze, możemy tu wskazać, że rządzenie daje narzędzia i wsparcie, jakimi nie dysponują pretendenci. Wymienia się tu częstą ekspozycję medialną, spotkania z wyborcami, w tym obecność na różnego rodzaju uroczystościach, a wszystko to z racji pełnionej funkcji. Po drugie, rządzący mogą zwiększać szanse ponownego wyboru przez manipulacje budżetowe (tzw. political budget cycle). Polega to na zwiększaniu wydatków i obniżaniu obciążeń fiskalnych w okresie przedwyborczym, co wyborcy mają zauważać i nagradzać, choć istnieją doniesienia twierdzące, że w okrzepłych demokracjach o rozwiniętej gospodarce takie działania mogą dla inkumbentów przynosić efekt odwrotny od oczekiwanego [np. Peltzman 1992]. Po trzecie, wzrost szans reelekcji może być pochodną zabiegów rządzących w kierunku budowania i podtrzymywania wydajnych dla nich sieci powiązań klientelistycznych. W praktyce struktury takie mogą wychodzić daleko poza klasyczną diadę patron-klient [Tarkowski 1994] i przybierać postać klientelizmu masowego, indywidualnego, kronizmu czy parantelizmu [Własiuk 2011] 2. Wreszcie po czwarte, w areale działań rządzących w ramach charakteryzowanych stanowisk (wójt, burmistrz) pozostaje mniej lub bardziej sprawne wykorzystywanie marketingu politycznego, np. w postaci autopromocji, do czego w przypadku gmin wiejskich służą informacyjne biuletyny gminne czy cykliczne spotkania z wyborcami.

Katalogu czynników moderujących szanse reelekcji nie zamykają wspomniane uwarunkowania strukturalne (jak posiadanie władzy) i intencjonalne (manipulacje budżetowe, inwestowanie w relacje klientelistyczne czy w autopromocję). Katalog ten możemy dalej rozwijać, wskazując na przykład na wpływ pozycji na karcie wyborczej (co ma też znaczenie w wyborach open race, czyli rozgrywanych bez obecności inkumbenta i jest to również przewaga strukturalna, czyli w niewielkim stopniu zależna od kandydata w tych wyborach). Następnie otwiera się przed nami cały katalog cech, które możemy określać jako czynniki indywidualne opisujące kandydata, jak: płeć, wiek, poziom wykształcenia, doświadczenia zawodowe [Taylor, McEleny 2015], doświadczenia w zajmowaniu innych stanowisk urzędniczych i z wyboru [Krebs 1998; Bartnicki, Kowalik 2017] czy formalna afiliacja komitetu wyborczego.

2 W zakresie ujmowania zjawiska klientelizmu na poziomie gmin interesujące założenie przedstawił Wojciech Łukowski podczas dyskusji nad projektem badawczym, na kanwie którego powstał niniejszy artykuł (Warszawa, styczeń 2016 roku). Jego zdaniem, relacje klientelistyczne na poziomie gmin należy dzielić na „klientelizm korupcyjny” i ,funkcjonalny”. Pierwszy manifestuje się zwyczajowymi przejawami tego zjawiska (np. relacje wymiany). Drugi nie ma służyć zwiększaniu szans uzyskania korzyści jednostkowych (w tym reelekcji) przez wójta, burmistrza, a jest niejako powinnością włodarza wobec społeczności lokalnej, „bo nie istnieje żaden inny wykształcony mechanizm społecznej kooperacji. Jeśli zatem ktoś odważy się na próbę wyjścia poza ten mechanizm, bardzo często skazuje lokalną społeczność na gorszące konflikty, walkę o władzę, organizowanie referendów odwoławczych etc. więc również w konsekwencji prowadzi to do obniżenia skuteczności sprawowania władzy, która w społecznym odbiorze jest redukowana do "załatwiania» przez władzę różnych spraw - od nowego chodnika po wielkie projekty unijne. Burmistrz czy wójt może budować zatem system lojalności przez np. zapewnianie stabilności zatrudnienia w placówkach publicznych, jednak w swej motywacji nie po to, aby zapewnić sobie reelekcję, ale głównie po to, aby zapewnić spokój społeczny konieczny do skutecznego rządzenia" (Wojciech Łukowski, Warszawa, styczeń 2016). 
Rolę moderatorów szans ponownego wyboru odgrywają także cechy okręgów wyborczych (w tym przypadku gmin). Globalnie, nawiązując do odkryć dostępnych w literaturze światowej, możemy wskazać, że w charakteryzowanych wyborach głównym czynnikiem wpływu po stronie gminy (okręgu wyborczego) pozostaje liczba jej ludności. Obserwacje z Kanady [Kushner, Siegel, Stanwick 1997], sugerują, że pozycja inkumbentów jest silniejsza w dużych ludnościowo jednostkach niż w jednostkach o mniejszej liczbie ludności. Korespondują z tym doniesienia z badań nad zachowaniami politycznymi w zakresie społeczności lokalnych w USA [Oliver, Ha 2007: 404]. Wnioski z nich płynące stwierdzają między innymi, że spadek liczebności zbiorowości i wzrost jej zróżnicowania powoduje wzrost zainteresowania sprawami lokalnymi [Oliver, Ha 2007: 404]. Jak można sądzić, ów wzrost zainteresowania lokalną społecznością przez jej członków jest wynikiem większego prawdopodobieństwa bezpośredniego odczuwania lokalnych problemów w relatywnie niewielkich zbiorowościach. Wraz ze wzrostem liczby ludności maleje szansa, że mieszkańcy zostaną bezpośrednio zaangażowani w lokalne sprawy i problemy. Jednocześnie, zaangażowanie w życie wspólnoty przekłada się na większe szanse bezpośredniego poznania pretendentów do obieralnych stanowisk. Zaś tym, którzy mają ambicje polityczne, względnie niewielka liczba ludności podmiotu ułatwia dotarcie do głosujących, choćby za pomocą kampanii door-to-door [Chmielewski, Malinowski 2004]. Wzrost liczby ludności w przypadku wyborów lokalnych powoduje, że wyborcy stają się coraz bardziej podatni na sygnały niskokosztowe, takie jak status inkumbenta czy formalna afiliacja polityczna kandydata. Maleją też szanse wyborców na bezpośrednie kontakty z inkumbentem i pretendentami do stanowiska, a coraz większą rolę odgrywają kontakty zapośredniczone przez media. Wyborca wielkomiejski relatywnie słabo interesuje się wyborami lokalnymi. Tendencja spadku frekwencji wyborczej wraz ze wzrostem liczby ludności w tego typu wyborach jest obserwowana nie tylko w Polsce [Swianiewicz 2010]. Zależność tę wyjaśnia teoria słabnięcia społeczności [Skarżyńska 2006]. Powyższe wyjaśnia, dlaczego w Polsce w gminach liczących więcej niż 100 tys. ludności inkumbenci w tych wyborach są w zasadzie nieusuwalni, a szansa dla pretendentów pojawia się wówczas, gdy rządzący nie kandyduje. Najniższy poziom rotacji w każdych dotychczasowych wyborach bezpośrednich do przedstawianych stanowisk charakteryzuje ośrodki powyżej 100 tys. ludności, gminy wiejskie i miasta na prawach powiatu. Rotacja jest najwyższa w gminach miejskich, a następnie w miejsko-wiejskich. W tych pierwszych w ostatnich wyborach zmieniła się prawie połowa włodarzy. Przyczyn relatywnie niskiej wymiany włodarzy w gminach wiejskich można upatrywać w niskiej podaży kandydatów w tych jednostkach (korelacja średnia w zakresie liczby ludności i liczby kandydatów w tego typu wyborach waha się od 0,3 do 0,4). W gminach miejskich i miejsko-wiejskich wzmożona rotacja jest pochodną sugerowanych prawidłowości oraz - zapewne - silniejszego odczuwania deficytów ekonomicznych.

Liczba ludności gminy warunkuje profil pozostałych zmiennych charakteryzujących gminy, przez to dookreśla zakres szans gminnych włodarzy w ich staraniach 
o reelekcję. Dzieje się tak z dwóch powodów, po pierwsze ludność gminy wyznacza w miarę stałe wartości kwantyfikowalnych cech gmin, a po drugie dookreśla ,wrażliwość” wyborców pod względem reelekcji włodarza na wartości różnych cech gmin. Przykładowo wraz ze wzrostem liczby ludności zwiększa się prawdopodobieństwo doceniania przez wyborców wydatków na kulturę. Wysoki poziom tego typu wydatków w relatywnie małych ludnościowo gminach nie będzie przekładać się na zwiększanie szans reelekcji wójta czy burmistrza, bo głosujący w takich jednostkach mają inny wachlarz potrzeb, a przez to ich uwaga ogniskuje się na wartościach innych zmiennych. Podobne zależności dotyczą wielu innych zmiennych, których natężeniem w większym lub mniejszym zakresie może sterować lokalny włodarz. Z analizy danych ilościowych i rozmów z przedstawicielami władz gminnych wynika, że rządzący mogą być w pewnym zakresie świadomi istnienia tego typu uwarunkowań.

Jednocześnie przy tym, co dookreślono powyżej, należy mieć też na uwadze, że dynamika życia gminnego częstokroć wymyka się możliwościom kwantyfikacji. Jako przykład obrazujący ową dynamikę można wskazać kazus „ściętego drzewa” podawany przez Erica Olivera, Shanga Ha i Zacharego Callena dla zobrazowania labilności politycznego życia lokalnej społeczności, które wymyka się kwantyfikacji [Oliver, Ha, Callen 2012]. Autorzy sugerują, że spirala potencjalnego lokalnego konfliktu może mieć swój początek w momencie podjęcia błahej decyzji, np. ścięcia konkretnego drzewa, a kończyć się zmianami personalnymi na firmamencie lokalnej sceny politycznej. Początkowa mało istotna z punktu widzenia obserwatora zewnętrznego decyzja czy działanie w konsekwencji może doprowadzić do daleko idących skutków. Autorzy ci sugerują, że osoba spoza środowiska taki konflikt najprawdopodobniej zbagatelizuje, uzna za irracjonalny i nie będzie na ogół w stanie zrozumieć perspektywy mieszkańców.

\section{PRZEWIDYWANIA}

Po wstępnych analizach danych ilościowych wyrażających wartości cech gmin i kandydatów, na podstawie wniosków płynących z literatury przedmiotu oraz badań terenowych w ramach projektu, którego dotyczy niniejszy artykuł, przyjęto, że kwantyfikowane cechy kandydatów i gmin (niebędących miastami na prawach powiatu, w których ostatnie wybory w 2014 roku miały charakter konkurencyjny i odbyły się w regulaminowym terminie), mogące w ich przypadku moderować szanse reelekcji, to:

1. Liczba konkurentów w wyborach w 2014 roku (kon) - wzrost wartości tej zmiennej będzie zmniejszał szanse reelekcji inkumbenta.

2. Staż na stanowisku kierownika gminnej egzekutywy (staż) - przyjęto, że najwyższe szanse reelekcji w 2014 roku mieli inkumbenci ubiegający się o drugą kadencję (pierwszą reelekcję), co wynika z tendencji sophomore surge, która sugeruje, że najmłodsi stażem odnotowują najwyższy wzrost poparcia w stosunku do wyborów 
poprzednich względem pozostałych inkumbentów. Długotrwałe pozostawanie na stanowisku osłabia inkumbenta i zwiększa szansę wzmocnienia jego przeciwników [Veiga, Veiga 2006].

3. Posiadanie formalnej większości w radzie gminy z wyborów w 2010 roku $(w)$; zmienna ta powinna pozytywnie oddziaływać na szanse ponownego wyboru inkumbenta w 2014 roku. W tym przypadku, jak i w przypadku typinc oddziaływanie tej zmiennej na szanse reelekcji reguluje wielkość ludnościowa jednostki. W dużych ośrodkach posiadanie większości w radzie jest ważniejsze z punktu widzenia uzyskania reelekcji niż w mniejszych ludnościowo gminach. Przemawiają za tym dwa czynniki: po pierwsze, w dużych jednostkach znaczenie ma identyfikacja (w tym nieformalne poparcie partii politycznej) partyjna włodarzy i radnych, co w praktyce oznacza wysokie prawdopodobieństwo upolityczniania konfliktów; po drugie, im mniej ludna gmina, tym większe prawdopodobieństwo, że opozycyjni radni ulegną wpływowi gminnego włodarza, bo nie będą posiadać takich obligacji jak w dużych jednostkach do obrony swojego stanowiska, a częściej strategii swojej partii politycznej. W mniejszych ośrodkach rzadziej też spotkamy radnych $\mathrm{z}$ afiliacjami partyjnymi. W małoludnych gminach, w których możliwości aktywności zawodowej są ograniczone, radni są też często w zakresie swojego zatrudnienia bezpośrednio albo pośrednio zależni od woli wójta/burmistrza, co często powoduje, że przynależność do komitetu opozycyjnego w takich radach to fikcja ${ }^{3}$.

4. Formalna afiliacja komitetu wyborczego inkumbenta w 2014 roku (typinc); przyjęto, że w zakresie analizowanych gmin zmienna ta nie powinna wykazywać istotnego wpływu. Choć teoretycznie prawdopodobieństwo oddziaływania tej zmiennej powinno wzrastać wraz ze wzrostem liczby ludności gminy. W dużych, a szczególnie w największych ośrodkach pozytywny wpływ na szanse reelekcji powinna wykazywać afiliacja partyjna komitetu wyborczego inkumbenta, co wynika z wcześniejszych uwag sugerujących, że wyborca wielkomiejski skupi się raczej na zewnętrznych łatwych do odnotowania sygnałach. Z kolei w małych gminach nie należy oczekiwać, że wpływ tej zmiennej będzie miał znaczenie. Tendencje w tym zakresie podpowiada zresztą obserwacja danych empirycznych z dotychczasowych wyborów - im większa ludnościowo jednostka, tym więcej kandydatów afiliowanych partyjnie możemy się spodziewać, co dotyczy również kandydujących inkumbentów.

5. Wydatki majątkowe inwestycyjne per capita w roku 2014 (wmipc); dobroczynny wpływ wysokich wartości analogicznych zmiennych w latach wyborczych na

3 Respondenci w badaniach terenowych realizowanych w ramach projektu, na podstawie wyników którego ten artykuł powstał, w małoludnych gminach sugerowali często, że radnymi nie powinny być osoby, które zawodowo pozostają w bezpośredniej albo pośredniej zależności od lokalnego włodarza, np. nauczyciele (szkół podstawowych), którzy często zasiadają w radach. Kwestia funkcjonowania opozycji względem komitetu włodarza w radach małych gmin ma w zasadzie charakter formalny, mimo że początki są czasami nader obiecujące. Sposoby podporządkowywania radnych przez włodarza są dość zróżnicowane - od zatrudniania radnych czy ich bliskich, po np. zapraszanie wszystkich radnych na obiad przed sesją, na której głosuje się nad absolutorium. 
losy inkumbentów wielokrotnie już dowiedziono [np. Veiga, Veiga 2007]. Przyjmuję, że wzrost wartości wmipc zwiększa szanse reelekcji w analizowanych wyborach i w tej grupie gmin.

6. Dynamika odsetka podmiotów sektora publicznego wśród podmiotów gospodarki narodowej ogółem w latach 2011-2014 (publW); zmienna informuje o procentowej zmianie udziału jednostek sektora publicznego w masie podmiotów gospodarki narodowej ogółem w 2014 roku względem roku 2011. Można oczekiwać, że w mniejszych ludnościowo gminach wzrost wartości tej zmiennej będzie zwiększać szanse ponownego wyboru inkumbenta. Im większa liczba ludności gminy, tym zachodzi niższe prawdopodobieństwo odnotowania istotnego wpływu tej zmiennej $\mathrm{z}$ uwagi na fakt wzrastającej liczby pozostałych podmiotów gospodarki narodowej wraz ze wzrostem liczby ludności. Zmienną tę mogłaby efektywniej zastąpić zmienna informująca o udziale pracujących w sektorze publicznym w danej gminie, jednak według informacji uzyskanej od GUS taka zmienna nie jest archiwizowana, stąd uciekamy się do jej mniej efektywnego odpowiednika. Charakteryzowana zmienna jest też interesująca jeszcze z innego powodu. Według brzmienia artykułu 10 ustawy o gospodarce komunalnej z dnia 20 grudnia 1996 roku, gminy mogą powoływać lub przystępować do spółek prawa handlowego na podstawie niedookreślonych przesłanek. W praktyce może to skutkować tym, co stwierdziła kontrola NIK w kilku gminach woj. łódzkiego. Kontrolowane gminy podejmowały działalności zaburzające swobodę konkurencji gospodarczej, tj.: badania opinii i rynku czy sprzedaż używek ${ }^{4}$.

7. Liczba pracujących na 1 tys. ludności gminy w 2014 roku (prac); oczekuje się, że wzrost wartości tej zmiennej podnosi szanse ponownego wyboru ubiegającego się o reelekcję. Zmienna ta może się wykazywać wyższą wydajnością predykcyjną niż na przykład odsetek zarejestrowanych bezrobotnych w liczbie ludności w wieku produkcyjnym; różnie operacjonalizowane zmienne obrazujące liczbę różnorakich typów podmiotów gospodarki narodowej zarejestrowanych w gminie (wg wielkości zatrudnienia i/lub struktury własnościowej); czy też wysokość wpływów podatkowych CIT albo podatku od nieruchomości.

8. Odsetek zapisanych na wniosek własny do rejestru stałego wyborców w gminie, w stosunku do wyborców wpisanych z urzędu w IV kwartale 2014 roku $(\mathrm{vm})^{5}$; zmienna odnotowuje liczbę uprawnionych do głosowania zapisujących się w danej gminie do stałego rejestru wyborców (tzw. karty zielone) - kryterium zamieszkiwa-

${ }^{4}$ NIK, Funkcjonowanie spótek komunalnych w województwie łódzkim, s. 9, https://www.nik.gov.pl/ plik/id,7771,vp,9739.pdf (dostęp: 1.07.2015).

5 Funkcjonowanie rejestru stałego wyborców normuje art. 18 i 19 ustawy z dn. 5 stycznia 2011 roku Kodeks wyborczy (Dz.U. z 2017 r. poz. 15) oraz rozporządzenie Ministra Spraw Wewnętrznych i Administracji z 27 lipca 2011 roku (Dz.U. nr 158, poz. 941). Analiza uwzględnia również wpisy w ramach litery c wg brzmienia Rozporządzenia Ministra Spraw Wewnętrznych i Administracji z dnia 11 marca 2004 roku w sprawie rejestru wyborców oraz trybu przekazywania przez Rzeczpospolitą Polską innym państwom członkowskim Unii Europejskiej danych zawartych w tym rejestrze (Dz.U. $2004 \mathrm{nr} 42$ poz. $388 \S 3$ ust. 2 pkt 2, litera c). Oznacza to, że uwzględniono również osoby, które w rejestrze wyborców wskazywały inny adres zamieszkania na obszarze gminy niż adres ich zameldowania na pobyt stały. 
nia. Wpisanie do rejestru skutkuje zwiększeniem liczby uprawnionych do głosowania w danej gminie, do której rejestru wpis nastąpił, i jednocześnie powoduje ubytek liczby głosujących w gminie, w której dotychczas wyborca był zapisany w rejestrze (tzw. karty różowe). Rozwiązanie takie daje wyborcy możliwość wyboru gminy, w której będzie mógł głosować, m.in. w wyborach samorządowych, ze względu na miejsce faktycznego zamieszkiwania, a nie zameldowania. Jednocześnie badania terenowe w ramach projektu, na podstawie których powstał niniejszy artykuł, ujawniają możliwość występowania niepokojących tendencji związanych z tą instytucją. Osoby, z którymi przeprowadzono wywiady w wybranych gminach, w niektórych z nich wskazywały na instrumentalne wykorzystywanie możliwości wpisywania się na wniosek własny do rejestru wyborców. Wprowadzanie „swoich wyborców” ma być stosowane w niektórych gminach tak przez ubiegających się o reelekcję inkumbentów, jak i przez pretendentów. Jednocześnie trudno jest dowieść - przy wykorzystaniu danych empirycznych - intencjonalnego podłoża działania aktorów lokalnych w tym zakresie. Można przyjąć, że jest to jedno z narzędzi, którymi mogą się posługiwać lokalni aktorzy polityczni, aby zwiększyć szanse swojego wyboru w tego typu rozgrywkach. Można zakładać, że wyborcy, którzy są wprowadzani do rejestru w ostatnim kwartale roku wyborczego, mogą ,reprezentować” oponentów inkumbenta. Ten ostatni bowiem - teoretycznie - powinien wprowadzać „swoich wyborców" do rejestru przez cały okres kadencji i nie zwlekać do ostatniego kwartału roku wyborczego. Z kolei w przypadku oponentów decyzja o kandydowaniu zapada często przed wyborami, a jeżeli tak, to ewentualne wprowadzanie przez oponentów „swoich wyborców” do rejestru powinno się kumulować w ostatnim kwartale roku wyborczego. Jednocześnie wpisy do rejestru w tym okresie mogą pochodzić od nowo zamieszkałych niemających jeszcze silnych relacji z daną gminą, którzy odkładali to do ostatniego możliwego momentu przed wyborami. Wnioski z badań terenowych w zakresie możliwego oddziaływania zmiennej vm na szanse reelekcji i wpływu na wynik rozgrywki wyborczej sugerują między innymi, że w niektórych gminach liczących do 10 tys. ludności skala wpisów intencjonalnych może dochodzić do kilkuset osób (w jednej z gmin wskazywano na ok. $200 \mathrm{w}$ okresie całej kadencji), a proces ten jest rozłożony w czasie i nie musi się koncentrować w okresie przedwyborczym, szczególnie ze strony rządzących, którzy w tym celu mają mobilizować na przykład pracowników urzędu gminy, aby takich wyborców ,pozyskiwali”, ewentualnie sami wpisywali się do rejestru albo meldowali się na terenie gminy. Respondenci deklarowali, że ,pozyskani wyborcy” mogą być wpisywani grupami na kilka wybranych adresów i niekoniecznie muszą być „dystrybuowani” na dużą liczbę adresów na terenie gminy. Zarówno rządzący, jak i ich oponenci doskonale zdają sobie sprawę z możliwości, jakie oferuje wpisywanie wyborców do rejestru stałego w gminie, a ewentualne protesty wyborcze tym motywowane są oddalane, trudno jest bowiem udowodnić intencjonalność takich działań. W zakresie tego zagadnienia pozostaje jeszcze wiele niejasności i pytań, jak choćby o możliwość i skalę aktywowania w kolejnych wyborach raz 
„wprowadzonych wyborców” czy kontrolowanie „swoich wyborców” w zakresie tego, na kogo faktycznie oddają oni głosy. Poza tym nie jest możliwe wydzielenie tych, którzy wpisują się do rejestru na kryterium zamieszkania na podstawie własnej decyzji, od tych wyborców, którzy zostali przez kogoś „zaproszeni” do wpisywania się. Wreszcie nie sposób jest określić liczby stronników danego kandydata, którzy meldują się na terenie gminy, wówczas do rejestru są wpisywani z urzędu, czego zmienna $v m$ nie uwzględnia. Zmienna $v m$ wykazuje niski poziom korelacji z oddaleniem gminy od miasta wojewódzkiego (oraz najbliższego miasta wojewódzkiego) w kilometrach, dlatego można odrzucić założenie, że wyborcy wpisują się do gmin położonych przy miastach wojewódzkich, bo przykładowo w nich zamieszkują, a pracują nadal w mieście wojewódzkim. Jak wskazano, zagadnienie to wymaga jeszcze odrębnego opracowania ze względu na fakt, że - hipotetycznie - zjawisko intencjonalnego wpisywania się do rejestru stałego wyborców w danej gminie może modyfikować szansę zwycięstwa wyborczego, a w niektórych przypadkach - zakładamy, że w nielicznych - o takim zwycięstwie przesądza. Jednocześnie musimy pamiętać, że możliwości w zakresie przeprowadzenia empirycznego dowodu są w tym przypadku dalece limitowane. W świetle powyższego wzrost wartości zmiennej $v m \mathrm{w}$ nielicznych tylko przypadkach może zwiększać szanse reelekcji, globalnie jednak należy oczekiwać zależności odwrotnej jako efektu decydowania wyborczego, w którym na nowo wpisanych wyborców nie będzie oddziaływać efekt inkumbenta, dlatego w większym zakresie niż dotychczasowi mieszkańcy będą oni skłonni popierać pretendentów.

9. Dynamika odsetka ludności gminy z dostępem do sieci kanalizacyjnej w okresie kadencji od 2011 do 2014 roku (dynK); zmienna ta powinna efektywniej moderować szansę reelekcji niż jej wartość jedynie z roku wyborczego. Poza tym zaspokajanie deficytów w tym zakresie oznacza odmienną specyfikę fluktuacji tej zmiennej od zmiennych poddających się moderacji intencjonalnej w ramach cyklu wyborczego (wmipc). Zmienna ta oddaje zakres uzbrojenia w infrastrukturę podstawową i wykazuje większe deficyty niż zaspokojenie dostępności do sieci wodociągowej, a jednocześnie cechuje się niższym deficytem niż dostępność ludności do sieci gazowniczej, najbardziej kosztownej w wytworzeniu i eksploatacji.

10. Dynamika odsetka dzieci w wieku 3-6 lat w gminie objętych wychowaniem przedszkolnym w latach 2011-2013 (kids); zmienną tą możemy uznać za stymulantę, której wzrost powinien zwiększać szansę reelekcji.

11. Liczba fundacji, stowarzyszeń i organizacji społecznych poza OSP na 10 tys. ludności w 2014 roku ( $f_{s o}$ ); im większa ludnościowo gmina, tym większe prawdopodobieństwo, że wpływ tej zmiennej powinien wykazywać się istotnością statystyczną, a wzrost jej wartości niwelować szansę reelekcji. W relatywnie małych ludnościowo gminach można oczekiwać, że liczebność podmiotów tego typu będzie niska oraz że podmioty te będą odczuwać większą zależność od władz gminnych i jednocześnie istnieje wyższe prawdopodobieństwo, że będą powoływane i zarządzane przez osoby związane z lokalnymi władzami. 
12. Wydatki gminy na pomoc społeczną jako procent ogółu wydatków gminy w 2014 roku (pom); wyższe wartości zmiennej pom w roku wyborczym będą obniżać szansę reelekcji inkumbenta. Zmienna ta jest w stopniu średnim ujemnie skorelowana $\mathrm{z}$ wydatkami majątkowymi per capita $\mathrm{w} 2014$ roku (wmipc), wzrost wartości transferów na pomoc społeczną idzie w parze z niższym wydatkowaniem na inwestycje. Poza tym, jak informują lokalni włodarze w wywiadach terenowych, społeczności gminne mają negatywnie odnosić się do zwiększania wydatków tego typu, wreszcie, w opinii wójtów i burmistrzów, pobierający zwykle pomoc społeczną mają nie uczestniczyć w głosowaniu. Choć napotkano również opinie, że grupy beneficjentów pomocy społecznej mają być zdyscyplinowanymi dostarczycielami głosów wyborczych, szczególnie kiedy zostaną dodatkowo „zmotywowane” przez urzędników albo przedstawicieli lokalnej władzy (np. radnych czy sołtysów). Środkami takiej motywacji bywa na przykład przydział węgla dostarczany w okresie bezpośrednio przed wyborami i oczywiście obietnica dalszego świadczenia środków pomocy przez urząd, bez względu na fakt czy GOPS/MOPS może faktycznie takiej pomocy pozbawić, czy też nie.

13. Liczba Ochotniczych Straży Pożarnych (OSP) na 10 tys. ludności w 2014 roku (osp); zainteresowanie tymi podmiotami wynika z kilku przesłanek. Po pierwsze, jednostki OSP obecne są właściwie w każdej gminie w kraju; po drugie, czasookres ich nieprzerwanego trwania na ziemiach polskich jest względnie długi; po trzecie, większość tych jednostek należy do scentralizowanej struktury na poziomie krajowym (ZOSP RP), na której czele stoją politycy PSL rozpoznawalni na arenie krajowej; po czwarte, OSP pełnią wiele ról i spełniają wiele funkcji dla społeczności lokalnych, do których należy wliczać budowanie kapitału społecznego w zakresie mezostruktur; po piąte wreszcie, relacje polityków PSL szczebla centralnego z tymi podmiotami, w momentach kiedy PSL był w koalicji rządzącej, wskazywały na możliwości wzbudzania parantelizmu [Peters 1995]. Powyższe sugeruje, że OSP mogą być efektywnymi kreatorami lokalnej sceny politycznej, a nie jedynie podporządkowanymi władzy. Zagrożeniem dla wykazywania przez zmienną osp efektywnej predykcji jest fakt, że odnotowuje ona jedynie liczbę podmiotów, a nie liczbę członków w gminie w ramach tych podmiotów, podobnie zresztą jak zmienna fso.

14. Liczba ludności gminy w 2014 roku (lud). Wartości zmiennej ciągłej liczba ludności gminy (np. według stanu na 31 grudnia 2014 roku) w zestawieniu z wymianą rządzących wykazują zależność krzywoliniową. Najniższa rotacja występuje w najbardziej (> 100 tys. ludności), a następnie w najmniej ludnych gminach, a najwyższa jest $\mathrm{w}$ gminach 20-100 tys. mieszkańców (głównie miejskie i miejsko-wiejskie). Taka tendencja utrzymuje się właściwie od wyborów w 2006 roku. W tym zakresie jest możliwe wprowadzanie do modeli regresji logistycznej zmiennej obrazującej liczbę ludności w postaci zmiennej ciągłej logarytmizowanej, nieadekwatnie odzwierciedli to jednak rozkład tego predyktora względem zmiennej zależnej. Z tego względu lepszym rozwiązaniem wydaje się dyskretyzacja zmiennej niezależnej liczba ludności gminy do postaci predyktora binarnego kotwiczonego na wartości mediany 
(7526) w zakresie przyjmowanego zbioru obserwacji, w którym najludniejsza gmina liczyła pod koniec 2014 roku 78180 mieszkańców (załącznik 2). Należy również dodać, że liczba ludności gminy, jak sugerowano wcześniej, wyznacza wartości brzegowe wszystkich cech charakteryzujących gminy oraz moderuje zachowania wyborcze. W przypadku stosowanej macierzy danych substytutem tej zmiennej jest liczba kandydujących (kontrkandydatów) w tego typu wyborach (korelacja średnia: 0,3-0,4), czyli najsilniejszy predyktor prawdopodobieństwa reelekcji, za wyjątkiem gmin powyżej 100 tys. ludności. Z powyższych względów zmienna binarna ludmed posłuży głównie do wyznaczenia interakcji z pozostałymi zmiennymi objaśniającymi, a w modelach regresji będzie zastępowana liczbą kontrkandydatów (kon).

Katalog zmiennych niezależnych przedstawiono w załączniku 1 wraz z wykazaniem trybu operacjonalizacji, przewidywanym kierunkiem wpływu na zmienną zależną oraz źródłem pozyskania zmiennej.

DANE

Do bieżącej analizy służy jedna $\mathrm{z}$ baz danych utworzona na potrzeby projektu „Uwarunkowania reelekcji egzekutywy gminnej po 2002 roku w Polsce”. Obserwacje stanowią zakwalifikowane do analizy gminy $(\mathrm{N}=2476)$. Gminy wykluczone to Zielona Góra (miasto na prawach powiatu), Zielona Góra (gmina wiejska) oraz Jaśliska (gmina wiejska). W dwóch pierwszych w 2014 roku wyborów samorządowych nie przeprowadzano z powodu ich połączenia, z kolei gmina Jaśliska na mapie administracyjnej funkcjonuje od 1.01.2010 roku, jako gmina wydzielona z obszaru gminy Dukla. Obserwacje opisano wielozakresowym katalogiem cech charakteryzujących gminy (profil społeczny, kulturowy, polityczny i gospodarczy w postaci bezwzględnej oraz wysoko przetworzonej) i kandydatów (w zakresie ich cech indywidualnych). Pozwala to na weryfikowanie założeń teoretycznych, doniesień empirycznych oraz testowanie wpływu wybranych zmiennych kwantyfikowanych w zakresie moderacji szans sukcesu wyborczego kierowników gminnej egzekutywy wyłanianych we wszystkich dotychczasowych wyborach bezpośrednich. Baza jest utworzona na podstawie dostępnych i nieodpłatnych źródeł statystyki publicznej, głównie takich jak PKW czy GUS, oraz projektów celowych; jak MojaPolis. W bieżącej analizie są stosowane także dane udostępnione przez Jerzego Bartkowskiego (w).

\section{METODOLOGIA}

Przedkładana analiza ma charakter bardziej konfirmacyjny niż eksploracyjny. W zakresie przewidywań o wpływie wytypowanych zmiennych opiera się bowiem na wnioskach empirycznych (np. wmipc) oraz ugruntowanych przewidywaniach teoretycznych (np. w, typinc czy staż), zaś strona eksploracyjna analizy najpełniej 
ujawnia się w przypadku zmiennej $v m$. Zastosowano tu wymiar przekrojowy analizy dla ostatniego czasookresu wyborów organu wykonawczego gmin. Do określenia, od czego i w jakim stopniu zależy prawdopodobieństwo reelekcji wójtów i burmistrzów w wyborach w 2014 roku, zastosowano regresję logistyczną [Rószkiewicz 2011]. Zmienna zależna jest zmienną binarną i przyjmuje wartość $0 \mathrm{w}$ przypadku, gdy w 2014 roku inkumbent nie otrzymał reelekcji, i wartość 1 w sytuacji odwrotnej. Operacjonalizacja zmiennych objaśniających zaprezentowano w załączniku 1, a statystyki opisowe tychże zmiennych w załączniku 2. Do porównawczej oceny jakości modeli złożonych z różnej liczby predyktorów jest stosowana miara AIC oraz minus 2 logarytm wiarygodności (-2log); do oceny efektywności modeli zastosowano miary z tablicy trafności; a do kontroli współliniowości zmiennych niezależnych miarę VIF. Raportowano też wartości istotności w teście Hosmera i Lemeshowa (pHL) oraz wartość R-kwadrat Nagelkerkego (RN). Modele budowano na próbie zbilansowanej (dobieranej), która równoważy proporcję porażek i sukcesów wyborczych, dzięki czemu eliminuje się obciążenia modeli w kierunku lepszego przewidywania sukcesów niż porażek, przez co uzyskujemy zbliżone wartości parametrów czułości i specyficzności w modelach.

$\mathrm{Z}$ wejściowej macierzy obserwacji $(\mathrm{N}=2476)$ wykluczono te gminy, w których w wyborach w 2014 roku: a) nie kandydował inkumbent (wybory open race); b) wybory rozstrzygano w III turze; c) wyboru organu wykonawczego dokonywała rada gminy; d) wyboru dokonywano przez losowanie wskutek remisu; e) kandydowała jedna osoba (wybory plebiscytowe); f) nie analizowano też wyborów rozgrywanych w miastach na prawach powiatu. W skutek tych działań osiągnięto $\mathrm{N}=1931$ obserwacji do analizy obejmujących wszystkie typy administracyjne gmin z wyjątkiem miast na prawach powiatu, w których wybory miały charakter konkurencyjny i rozstrzygnięto je $\mathrm{w}$ trybie regulaminowym. $\mathrm{Z}$ otrzymanej w taki sposób populacji generalnej $\mathrm{N}=1931$ (605 przypadków porażek i 1326 przypadków sukcesów) utworzono następnie próbę dobieraną. W tym celu zastosowano losowanie proste $46 \%$ obserwacji z puli sukcesów w populacji generalnej $(\mathrm{N}=1326)$. Ostatecznie dzięki temu utworzono próbę zbilansowaną liczącą $\mathrm{N}=1211$ obserwacji, w której znajdujemy $\mathrm{N}=605$ przypadków porażek i $\mathrm{N}=606$ przypadków sukcesów wyborczych inkumbentów ubiegających się o reelekcję w 2014 roku. Na próbie dobieranej (zbilansowanej) budowano metodą wprowadzania modele regresji logistycznej. W załączniku 2 czytelnik odnajdzie statystyki opisowe zmiennych niezależnych również dla próby dobieranej.

\section{ANALIZA}

W tabeli 1 zaproponowano modele regresji logistycznej bazujące na sugerowanych predyktorach. Model 1 utworzono na podstawie wszystkich zmiennych niezależnych zaangażowanych w analizie, nie bacząc na ryzyko nadmiernych współlinio- 
wości predyktorów, np. ludmed i kon czy wmipc i pom. W efekcie uzyskujemy model najbardziej wydajny wśród proponowanych (najniższe wartości AIC oraz -2log) i nadal akceptowalny poziom dopasowania danych $(\mathrm{pHL}=0,052)$ oraz wyjaśniający najwyższy poziom zmienności zmiennej objaśnianej $(\mathrm{RN}=0,208)$. Pozostałe modele tworzono, niwelując współliniowości zmiennych objaśniających. Propozycje w tym zakresie przedstawiają modele od 2 do $4 \mathrm{w}$ tabeli 1 . Model 2 zbliżony poziomem predykcji i efektywności do modelu 1 po eliminacji czterech predykotrów obecnych w modelu 1 charakteryzuje się sześcioma zmiennymi o istotnym poziomie wpływu na postać zmiennej objaśnianej. Z modelu tym wyeliminowano zmienną pom wykazującą relatywnie wysoki poziom korelacji ze zmienną wmipc; zmienną osp powiązaną ze zmienną fso; zmienną prac powiązaną m.in. z fso; dodatkowo zmienną ludmed, którą zastępuje tu poziom konkurencji wyborczej wyrażony przez zmienną kon. Modele 3 i 4 wyróżnia pogorszenie parametrów (trafność, AIC, -2log, RN). Modele te testują wpływ pozostałych zmiennych dobieranych w taki sposób, aby niwelować współliniowość predyktorów. W modelu 3 uzyskano istotność wpływu zmiennej osp, co nie byłoby możliwe, gdyby w tym modelu wprowadzić dodatkowo predyktory kon czy ludmed skorelowane z osp (wzrost liczby ludności oznacza wyższą konkurencję wyborczą, a w większych ludnościowo gminach maleją wartości zmiennej osp). Lekko przekroczony poziom istotności wykazuje również zmienna kids (w modelu $1 \mathrm{p}=0,084$; a w modelu $2 \mathrm{p}>0,1$ ). Ujawniamy też istotne i niwelujące szanse reelekcji przez zmienną pom. Z kolei stabilne i pozytywne oddziaływanie wykazuje $\mathrm{w}$ tym modelu, podobnie jak w dwóch poprzednich, zmienna publW. W modelu 4 jest testowany wpływ przede wszystkim zmiennej prac, gdzie wykazano jej istotne oddziaływanie na zmienną objaśnianą. Jednak eliminacja z tego modelu zmiennej kon spowoduje utratę istotnego wpływu zmiennej prac. W tej postaci model wykazuje jednak lepsze dopasowanie danych i wyższą efektywność predykcyjną, choć wpływ tej zmiennej można uznać za dyskusyjny.

Tabela 1. Proponowane modele regresji dla próby dobieranej $\mathrm{N}=1211$

\begin{tabular}{|l|c|c|c|c|c|c|c|c|c|c|}
\hline & \multicolumn{9}{|c|}{1} & \multicolumn{5}{|c|}{2} \\
\hline & $\mathrm{B}$ & $\mathrm{SE}$ & Wald & $p$ & $\operatorname{Exp}(\mathrm{B})$ & $\mathrm{B}$ & SE & Wald & $p$ & $\operatorname{Exp}(\mathrm{B})$ \\
\hline kon & $-0,409$ & 0,054 & 58,335 & 0,000 & 0,664 & $-0,403$ & 0,051 & 62,974 & 0,000 & 0,668 \\
\hline staż & $-0,799$ & 0,150 & 28,234 & 0,000 & 0,450 & $-0,772$ & 0,149 & 26,919 & 0,000 & 0,462 \\
\hline w & 0,603 & 0,139 & 18,692 & 0,000 & 1,827 & 0,611 & 0,137 & 19,803 & 0,000 & 1,842 \\
\hline typinc & $-0,152$ & 0,181 & 0,712 & 0,399 & 0,859 & $-0,145$ & 0,178 & 0,666 & 0,414 & 0,865 \\
\hline wmipc (log) & 0,527 & 0,108 & 24,016 & 0,000 & 1,694 & 0,620 & 0,098 & 40,087 & 0,000 & 1,859 \\
\hline publW & 0,262 & 0,115 & 5,209 & 0,022 & 1,300 & 0,287 & 0,113 & 6,409 & 0,011 & 1,332 \\
\hline prac (log) & 0,187 & 0,144 & 1,694 & 0,193 & 1,206 & & & & & \\
\hline vm+0,01 (log) & $-0,362$ & 0,083 & 18,957 & 0,000 & 0,696 & $-0,341$ & 0,077 & 19,423 & 0,000 & 0,711 \\
\hline dynK & 0,005 & 0,007 & 0,493 & 0,483 & 1,005 & 0,005 & 0,007 & 0,536 & 0,464 & 1,005 \\
\hline kids & 0,013 & 0,008 & 2,995 & 0,084 & 1,013 & 0,011 & 0,007 & 2,129 & 0,145 & 1,011 \\
\hline fso (log) & $-0,011$ & 0,139 & 0,007 & 0,936 & 0,989 & 0,003 & 0,125 & 0,001 & 0,982 & 1,003 \\
\hline
\end{tabular}




\begin{tabular}{|c|c|c|c|c|c|c|c|c|c|c|}
\hline & \multicolumn{5}{|c|}{1} & \multicolumn{5}{|c|}{2} \\
\hline & $\mathrm{B}$ & $\mathrm{SE}$ & Wald & $p$ & $\operatorname{Exp}(B)$ & $\mathrm{B}$ & $\mathrm{SE}$ & Wald & $p$ & $\operatorname{Exp}(B)$ \\
\hline pom (log) & $-0,443$ & 0,258 & 2,947 & 0,086 & 0,642 & & & & & \\
\hline $\operatorname{osp}(\log )$ & 0,057 & 0,087 & 0,431 & 0,512 & 1,059 & & & & & \\
\hline ludmed & $-0,096$ & 0,159 & 0,360 & 0,548 & 0,909 & & & & & \\
\hline Stała & $-1,658$ & 1,457 & 1,295 & 0,255 & 0,190 & $-2,560$ & 0,716 & 12,771 & 0,000 & 0,077 \\
\hline $\mathrm{N}$ & \multicolumn{5}{|c|}{1211} & \multicolumn{5}{|c|}{1211} \\
\hline Trafność & \multicolumn{5}{|c|}{68,1} & \multicolumn{5}{|c|}{67,2} \\
\hline Czułość & \multicolumn{5}{|c|}{68,9} & \multicolumn{5}{|c|}{68,8} \\
\hline Specyficzność & \multicolumn{5}{|c|}{67,3} & \multicolumn{5}{|c|}{65,5} \\
\hline $\mathrm{pHL} / \mathrm{RN}$ & \multicolumn{5}{|c|}{$0,52 / 0,208$} & \multicolumn{5}{|c|}{$0,95 / 0,202$} \\
\hline $\begin{array}{l}\text { Maks. VIF/ } \\
\text { AIC/-2log }\end{array}$ & \multicolumn{5}{|c|}{$1,87 / 1460,5 / 1430,495$} & \multicolumn{5}{|c|}{$1,16 / 1477,1 / 1455,069$} \\
\hline & \multicolumn{5}{|c|}{3} & \multicolumn{5}{|c|}{4} \\
\hline & $\mathrm{B}$ & SE & Wald & $p$ & $\operatorname{Exp}(B)$ & $\mathrm{B}$ & SE & Wald & $p$ & $\operatorname{Exp}(B)$ \\
\hline kon & & & & & & $-0,440$ & 0,051 & 74,850 & 0,000 & 0,644 \\
\hline$s t a \dot{z}$ & $-0,683$ & 0,140 & 23,938 & 0,000 & 0,505 & $-0,774$ & 0,145 & 28,636 & 0,000 & 0,461 \\
\hline$w$ & 0,736 & 0,131 & 31,644 & 0,000 & 2,088 & 0,608 & 0,134 & 20,718 & 0,000 & 1,837 \\
\hline publW & 0,221 & 0,106 & 4,356 & 0,037 & 1,247 & & & & & \\
\hline prac (log) & & & & & & 0,275 & 0,104 & 7,052 & 0,008 & 1,317 \\
\hline kids & 0,016 & 0,007 & 5,059 & 0,025 & 1,016 & 0,012 & 0,007 & 2,722 & 0,099 & 1,012 \\
\hline pom (log) & $-0,898$ & 0,208 & 18,694 & 0,000 & 0,407 & & & & & \\
\hline osp $(\log )$ & 0,153 & 0,063 & 5,884 & 0,015 & 1,165 & & & & & \\
\hline Stała & 2,301 & 0,579 & 15,779 & 0,000 & 9,984 & 0,027 & 0,495 & 0,003 & 0,957 & 1,027 \\
\hline $\mathrm{N}$ & \multicolumn{5}{|c|}{1211} & \multicolumn{5}{|c|}{1211} \\
\hline Trafność & \multicolumn{5}{|c|}{60,9} & \multicolumn{5}{|c|}{65,6} \\
\hline Czułość & \multicolumn{5}{|c|}{63,4} & \multicolumn{5}{|c|}{69,2} \\
\hline Specyficzność & \multicolumn{5}{|c|}{58,3} & \multicolumn{5}{|c|}{61,8} \\
\hline $\mathrm{pHL} / \mathrm{RN}$ & \multicolumn{5}{|c|}{$0,583 / 0,090$} & \multicolumn{5}{|c|}{$0,840 / 0,148$} \\
\hline $\begin{array}{l}\text { Maks. VIF/ } \\
\text { AIC/-2log }\end{array}$ & \multicolumn{5}{|c|}{$1,15 / 1564,5 / 1550,471$} & \multicolumn{5}{|c|}{$1,16 / 1528,8 / 1516,758$} \\
\hline
\end{tabular}

Źródło: Obliczenia własne na podst.: PKW, GUS, MojaPolis (MP) i danych udostępnionych przez Jerzego Bartkowskiego (JB).

$\mathrm{Z}$ kolei model $5 \mathrm{w}$ tabeli 2 wskazuje jedyną istotną interakcję zmiennej ludmed ze wszystkimi pozostałymi zmiennymi objaśniającymi. Wynika z tego, że posiadanie formalnej większości w radzie gminy z wyborów w 2010 roku (w) efektywniej zwiększa szanse reelekcji w gminach liczących powyżej 7526 ludności niż w gminach mniej ludnych (model 5), co może sugerować, że w mniej ludnych gminach lokalny włodarz jest w stanie skuteczniej podporządkować sobie opozycyjnych radnych. Z kolei w modelu 6 wykazano interakcję stażu (staż) i posiadania formalnej większości w radzie gminy z wyborów w 2010 roku (w), co możemy interpretować w ten sposób, że posiadanie większości formalnej w radzie istotnie podnosiło szansę reelekcji w 2014 roku w przypadku inkumbentów wielkokadencyjnych. 
Tabela 2. Modele regresji wykazujące efekt interakcji, $\mathrm{N}=1211$

\begin{tabular}{|c|c|c|c|c|c|}
\hline \multicolumn{6}{|c|}{5} \\
\hline & B & SE & Wald & $p$ & $\operatorname{Exp}(B)$ \\
\hline ludmed & $-0,447$ & 0,157 & 8,128 & 0,004 & 0,640 \\
\hline$w$ & 0,194 & 0,165 & 1,380 & 0,240 & 1,214 \\
\hline ludmed $x w$ & 0,804 & 0,241 & 11,157 & 0,001 & 2,234 \\
\hline Stała & 0,007 & 0,117 & 0,003 & 0,953 & 1,007 \\
\hline \multicolumn{6}{|c|}{6} \\
\hline & $\mathrm{B}$ & $\mathrm{SE}$ & Wald & $p$ & $\operatorname{Exp}(B)$ \\
\hline$w$ & 0,205 & 0,266 & 0,593 & 0,441 & 1,227 \\
\hline staż & $-0,875$ & 0,160 & 30,051 & 0,000 & 0,417 \\
\hline$w x \operatorname{staz}$ & 0,743 & 0,302 & 6,059 & 0,014 & 2,101 \\
\hline Stała & 0,257 & 0,120 & 4,571 & 0,033 & 1,293 \\
\hline
\end{tabular}

Źródło: Obliczenia własne na podst.: PKW, GUS, MojaPolis (MP) i danych udostępnionych przez Jerzego Bartkowskiego (JB).

Podsumowując, w zakresie analizowanych predyktorów i na zbiorze obserwacji pochodzących z próby dobieranej w wyborach organu wykonawczego gmin w 2014 roku:

1) poziom konkurencji wyborczej niwelował szanse reelekcji inkumbentów, w taki sposób, że każdy konkurent do stanowiska obniżał szanse reelekcji inkumbenta od 34 do $36 \%$;

2) ubiegający się o drugą i kolejne reelekcje mieli od 50 do $55 \%$ niższe szanse kolejnego wyboru niż ci, którzy ubiegali się wówczas o pierwszą reelekcję (drugą kadencję);

3) posiadanie formalnej większości w radzie gminy z wyborów w 2010 roku zwiększało szansę reelekcji w 2014 roku w zakresie od 82 do 108\%;

4) typ afiliacji komitetu wyborczego inkumbenta (partyjny/bezpartyjny) nie wykazywał istotnego wpływu na szanse zwycięstwa;

5) wzrost wydatków majątkowych inwestycyjnych per capita w roku 2014 o jeden w wartości logarytmu naturalnego zwiększał szanse reelekcji od 69 do $85 \%$;

6) wzrost o $1 \%$ odsetka udziału przedsiębiorstw publicznych w masie podmiotów gospodarki narodowej ogółem w gminie w okresie do 2011 do 2014 roku (publW) zwiększał szansę ponownego wyboru od 24 do 33\%;

7) wzrost liczby pracujących na 1000 mieszkańców w gminie w 2014 roku (prac) o jedną wartość logarytmu zwiększał szansę wyboru inkumbenta o 31\%;

8) wzrost o jedną wartość logarytmu odsetka zapisanych na wniosek własny do rejestru stałego wyborców w gminie w IV kwartale 2014 roku w stosunku do wpisanych z urzędu $(\mathrm{vm})$ obniżał szansę reelekcji inkumbenta od 29 do 31\%;

9) dynamika odsetka ludności gminy z dostępem do sieci kanalizacyjnej w latach 2011-2014 (dynK) nie moderowała szans wyborczych;

10) wzrost o $1 \%$ dzieci w gminie w wieku od 3 do 6 lat objętych wychowaniem przedszkolnym w roku 2013 względem roku 2011 wykazywał wzrost szans ponownego wyboru o $1 \%$;

11) liczba fundacji stowarzyszeń i organizacji społecznych poza OSP na 10 tys. ludności gminy w 2014 roku $(f s o)$ w analizowanym zbiorze obserwacji i w oto- 
czeniu sugerowanych predyktorów nie wykazywała wpływu na postać zmiennej zależnej;

12) wzrost o jedną wartość logarytmu wydatków gminy na pomoc społeczną jako odsetek ogółu wydatków gminy w 2014 roku (pom) obniżał szanse reelekcji o $60 \%$, jednak to wskazanie pochodzi z najsłabszego modelu;

13) wreszcie liczba OSP na 10 tys. ludności gminy w 2014 roku nie wykazywała wpływu na szansę reelekcji, istotność oddziaływania tej zmiennej w modelu 3 to pochodna jej relatywnie wysokiej korelacji z liczbą ludności, a przez to ze zmienną kon; eliminacja tych predyktorów z modelu i pozostawienie zmiennej osp obarcza jedynie tą ostatnią istotnym wpływem.

Dowiedziono, że istotnymi moderatorami sukcesu wyborczego inkumbentów w ostatnich wyborach na stanowiska wójtów i burmistrzów, oprócz tak oczywistego jak liczba konkurentów, jest też staż na stanowisku. Staż powyżej jednej kadencji obniżał szansę reelekcji inkumbentów, co oznacza, że nie umacniali oni swojej pozycji, choć należy też przy tym zauważyć, że w zakresie wyborów bezpośrednich ostatnie wybory dla ubiegających się o reelekcję na tych stanowiskach były najmniej łaskawe, podczas gdy w 2010 roku najwięcej spośród ubiegających się o reelekcję ją otrzymało. Pozytywnie i stabilnie szanse reelekcji zwiększała formalna większość w radzie gminy z wyborów w 2010 roku, która była szczególnie cenna w większych ludnościowo gminach (jak pokazuje model 5). Również im wyższy poziom wydatków majątkowych inwestycyjnych per capita osiągano w roku wyborczym, tym wyższa była szansa zwycięstwa w wyborach przez inkumbenta, jest to jednocześnie jeden z predyktorów (obok kon i staż), które najefektywniej wyznaczają szansę sukcesu wyborczego. Warto zauważyć, że mediana poziomu wydatków majątkowych inwestycyjnych w latach wyborczych wzrasta w miarę liczby kadencji na stanowisku. Dłużej rządzący potrafią wygenerować wyższe wydatkowanie tego typu niż rządzący krócej. Progresywny wzrost w tym zakresie jest zauważalny w każdych kolejnych wyborach od 2006 roku. Być może jest to sygnał pozytywny, jednak należy tu też zwrócić uwagę, w co się inwestuje. Wnioski z badań terenowych sugerują, że inwestycje twarde w najbogatszych gminach mogą wskazywać na przewartościowanie niektórych elementów infrastruktury. Przykładem jest nadmiernie rozbudowywana infrastruktura OSP (remizy i sprzęt gaśniczy, np. wozy strażackie), podczas gdy elementy te są w praktyce rzadko wykorzystywane i nie na skalę taką, do jakiej są przeznaczone; również budowa świetlic wiejskich, które jedynie w niewielkim stopniu są użytkowane. Wreszcie w zakresie związku wyższego wydatkowania na inwestycje w przypadku dłużej rządzących można chyba pokusić się o dalej idące założenie. Taki stan rzeczy może być powodowany także rentą położenia gminy (bliskość dużych ośrodków miejskich, węzłów komunikacyjnych, zasobów naturalnych czy inwestycji, na które lokalny włodarz nie ma wpływu). Wówczas wpływy podatkowe poprawią kondycję finansową gminy i na wydatki inwestycyjne pozostanie więcej środków, co pomoże lokalnym włodarzom utrzymać się na stanowisku. Wyższe szanse na ponowny wybór mieli również inkumbenci z tych 
gmin, w których w latach kadencji 2011-2014 wzrósł udział podmiotów sektora publicznego w masie podmiotów gospodarki narodowej ogółem. Być może jest to wynik relacji klientarnych na poziomie gmin. Bardziej jednoznaczne wnioski w tym zakresie oferowałaby zmienna uwzględniająca liczbę zatrudnianych przez urzędy gmin i jednostki gminne, jednak - jak już sugerowano - GUS nie archiwizuje takich danych i dlatego wykorzystano substytut takiej zmiennej w postaci publW. Wreszcie uwagę zwraca oddziaływanie odsetka wpisujących się na wniosek własny do stałego rejestru wyborców w gminie w IV kwartale 2014 roku ( vm), co - jak wskazano powinno obniżać szansę reelekcji inkumbentów i tak też się dzieje, prawdopodobnie dlatego że wyborcy wpisujący się do rejestru przed wyborami nie będą wrażliwi na efekt inkumbenta. Nie oznacza to oczywiście, że w pojedynczych przypadkach wpisy popleczników poszczególnych stron rozgrywki nie mogą efektywnie kreować wyniku wyborczego. Poza tym szansę reelekcji w ostatnich wyborach moderują także wydatki gminy na pomoc społeczną jako procent ogółu wydatków gminy w 2014 roku (pom). Wzrost wartości tej zmiennej w roku wyborczym obniżał szansę zwycięstwa inkumbenta. Zmienna pom w latach wyborów, poczynając od 2006 roku, wykazuje tendencję podobną do zmiennej wmipc w zestawieniu z liczbą kadencji rządzącego (licząc od 2002 roku), z tym że w przypadku pom mamy do czynienia z niższymi wartościami tej zmiennej w miarę wzrostu liczby kadencji na stanowisku. Im dłużej (od 2002 roku) na stanowisku lokalnego włodarza zasiada ta sama osoba, tym mniej wydatkuje w zakresie pom w poszczególnych latach wyborczych. Zatem spośród dwóch konkurencyjnych założeń, z których jedno sugeruje, że beneficjenci pomocy społecznej nie są dobrym „targetem” wpływu politycznego, trudno ich kontrolować i na nich wpływać, a drugie, że jest wprost przeciwnie, możemy chyba przyznać rację temu pierwszemu. W uzyskaniu reelekcji pomagała też wyższa liczba pracujących $\mathrm{w}$ gminie na 1 tys. jej ludności ( $\mathrm{rac}$ ). Zmienna ta nie jest skorelowana $\mathrm{z}$ wmipc, a słabo $(0,1)$ wiąże się z publW. Spośród pozostałych zmiennych dynamika odsetka dzieci w wieku 3-6 lat objętych wychowaniem przedszkolnym w latach 2011-2013 (kids) wykazuje marginalny, ale pozytywny wpływ na szansę reelekcji inkumbentów.

Zmiennymi niemoderującymi szans reelekcji w analizowanym zbiorze obserwacji okazała się między innymi afiliacja komitetu wyborczego inkumbenta (typinc). Ta zmienna binarna nie wykazuje też istotnego efektu interakcji z binarną zmienną ludmed. Szans reelekcji w 2014 roku nie budowała także dynamika udziału ludności z dostępem do sieci kanalizacyjnej w okresie od 2011 do 2014 roku (dynK). Uwrażliwienie wyborców na tę cechę jest dostrzegane w modelach koncentrujących się na gminach mniej ludnych w segmencie gmin wiejskich, w tym przypadku zakres analizowanych obserwacji uniemożliwia wykazanie istotności statystycznej. Zmienną, której wpływu nie udało się wykazać, jest również liczba fundacji, stowarzyszeń i organizacji społecznych poza OSP na 10 tys. ludności w 2014 roku ( fso) oraz liczba OSP na 10 tys. ludności w 2014 roku (osp). W tym drugim przypadku, jak wskazywano na etapie założeń, nie dysponujemy efektywniejszym odpowiednikiem tego predyktora w postaci liczby członków OSP w gminach, co mogłoby pomóc w ocenie sytuacji pod tym względem. 


\section{ZAKOŃCZENIE}

W artykule wykazano, jak wybrane cechy gmin i samych kandydujących wpływały na szansę reelekcji inkumbentów w wyborach organu wykonawczego gmin w 2014 roku. Predykcja dotyczy szerokiego spektrum gmin poza miastami na prawach powiatu, w których wybory miały charakter konkurencyjny i odbywały się w regulaminowym terminie, co z jednej strony pozwoliło na wskazanie dobrze ugruntowanych moderatorów reelekcji (liczba konkurentów, staż na stanowisku, posiadanie formalnej większości w radzie gminy z wyborów w 2010 roku, wydatki majątkowe inwestycyjne per capita w 2014 roku, dynamika podmiotów sektora publicznego w masie podmiotów gospodarki narodowej ogółem w latach 2011-2014 czy odsetek zapisanych na wniosek własny do rejestru stałego wyborców w gminie w stosunku do wyborców wpisanych z urzędu w IV kwartale 2014 roku), a z drugiej strony obniżyło wykazanie istotnego wpływu predyktorów oddziałujących segmentowo w ramach całego analizowanego zbioru obserwacji tworzących próbę dobieraną (dynamika odsetka ludności z dostępem do sieci kanalizacyjnej w gminie w okresie od 2011 do 2014 roku, typ komitetu wyborczego inkumbenta w 2014 roku, liczba fundacji, stowarzyszeń organizacji społecznych poza OSP na 10 tys. ludności gminy w 2014 roku czy liczba pracujących na 1 tys. ludności gminy w 2014 roku). Kolejne analizy mogą uwzględniać predykcję na zawężonych klastrach gmin. Warta rozważenia jest także perspektywa analizy na danych wzdłużnych, której wyniki mogą przedstawiać nieco inną, a niekoniecznie bardziej trafną perspektywę przewidywania wyników wyborów bezpośrednich do organu wykonawczego gmin.

Ujawnienie udziału osób trzecich: niektóre zmienne wykorzystywane w analizie były pozyskiwane i wstępnie przetwarzane przez Kamila Żukowskiego i Macieja Baranowskiego.

\section{BIBLIOGRAFIA}

Bartnicki, S., Kowalik, J. 2017. Wyborcza karuzela: staż parlamentarny jako czynnik sukcesu wyborczego kandydatów na wójta, burmistrza, prezydenta miasta, "Studia Humanistyczne AGH" (w druku).

Bober, J. i in. 2013. Narastajace dysfunkcje, zasadnicze dylematy, konieczne działania. Raport o stanie samorządności terytorialnej w Polsce, Uniwersytet Ekonomiczny w Krakowie, Małopolska Szkoła Administracji Publicznej, Kraków.

Chmielewski, T., Malinowski, K. 2004. Door-to-door jako instrument aktywizacji wyborców, w: Marketing polityczny, [w:] W poszukiwaniu strategii wyborczego sukcesu, M. Jeziński (red.), Wydawnictwo Adam Marszałek, Torun.

Drzonek, M. 2013. Reelekcje prezydentów miast $w$ wyborach bezpośrednich $w$ Polsce, Wydawnictwo Dante, Kraków.

Freier, R. 2015. The mayor 's advantage: Casual evidence on incumbency effects in German mayoral elections, "European Journal of Political Economy”, vol. 40, DOI: https://doi.org/10.1016/j.ejpoleco.2015.07.005. 
Gelman, A., King, G. 1990. Estimating incumbency advantage without bias, “American Journal of Political Science", vol. 34/4, DOI: https://doi.org/10.2307/2111475.

Krebs, T.B. 1998. The Determinants of Candidates Vote Share and Advantages of Incumbency in City Council Elections, "American Journal of Political Science", vol. 42 (3),

DOI: https://doi.org/10.2307/2991735.

Kushner, J., Siegel, D., Stanwick, H. 1997. Ontario Municipal Elections: Voting Trends and Determinants of Electoral Success in a Canadian Province, "Canadian Journal of Political Science", vol. 30/2, DOI: https://doi.org/10.1017/S0008423900016000.

Lee, D.S. 2001. The Electoral Advantage to Incumbency and Voters' Valuation of Politicians' Experience: A Regression Discontinuity Analysis of Elections to the U.S. House, National Bureau of Economic Research, Working Paper 8441.

Lee, D.S. 2008. Randomized Experiments from Non-random Selection in U.S. House Elections, "Journal of Econometrics", vol. 142/2, DOI: https://doi.org/10.1016/j.jeconom.2007.05.004.

Macdonald, B. 2014. Estimating Incumbency Advantages in African Politics: Regression discontinuity evidence from Zambian parliamentary and local government elections, Working paper Series 2014, London School of Economics and Political Science, London.

Oliver, J.E., Ha, S.E. 2007. Vote Choice in Suburban Elections, “American Political Science Review”, vol. 101 (3), DOI: https://doi.org/10.1017/S0003055407070323.

Oliver, J.E., Ha, S.E., Callen, Z. 2012. Local Elections and the Politics of Small-Scale Democracy, Princeton University Press, Princeton.

Peltzman, S. 1992. Voters as fiscal conservatives, "Quarterly Journal of Economics" 107(2), DOI: https://doi.org/10.2307/2118475.

Peters, G. 1995. Polityka i biurokracja państwowa, [w:] Władza i społeczeństwo, t. 1, J. Szczupaczyński (red.), Wydawnictwo Scholar, Warszawa.

Rószkiewicz, M. 2011. Analiza klienta, SPSS Polska, Kraków.

Skarżyńska, K. 2005. Człowiek a polityka. Zarys psychologii politycznej, Wydawnictwo Scholar, Warszawa. Stonecash, J.M. 2008. Reassessing the Incumbency Effect, Cambridge University Press, New York.

Swianiewicz, P. 2010. Czy rozmiar ma znaczenie? Zróżnicowanie opinii mieszkańców o funkcjonowaniu samorząów lokalnych w zależności od wielkości gminy, "Samorząd Terytorialny", nr 4.

Tarkowski, J. 1994. Patroni i klienci, Instytut Studiów Politycznych PAN, Warszawa.

Taylor, Z., McEleney, S. 2015. The advantages of incumbency and the determinants of municipal candidate vote share: The 2014 City of Toronto Election, https://www.assocsrv.ca/cpsa-acsp/2015event/ Taylor-McEleney.pdf (dostęp: 1.06.2016).

Titiunik, R. 2011. Incumbency Advantage in Brazil: Evidence from Municipal Mayor Elections (under revision), University of Michigan.

Trounstine, J. 2011. Evidence of a Local Incumbency Advantage, "Legislative Studies Quarterly", vol. 36/2, DOI: https://doi.org/10.1111/j.1939-9162.2011.00013.x.

Uppal, Y. 2009. The disadvantaged incumbents: estimating incumbency effects in Indian state legislatures, "Public Choice", vol. 138, DOI: https://doi.org/10.1007/s11127-008-9336-4.

Własiuk, T. 2011. Przejawy klientelizmu w życiu politycznym współczesnej Polski, Rozprawa doktorska napisana pod kierunkiem Jacka Raciborskiego na Uniwersytecie Warszawskim, Wydział Filozofii i Socjologii, Instytut Socjologii, maszynopis.

Veiga, L.G., Veiga, F.J. 2006. Does Opportunism Pay Off?, NIPE WP 5/2006, http://www.nipe.eeg.uminho. pt/Uploads/WP_1999-2008/NIPE_WP_5_2006.pdf(dostęp: 1.07.2016).

Veiga, L.G., Veiga, F.J. 2007. Political business cycles at the municipal level, "Public Choice", vol. 131, DOI: https://doi.org/10.1007/s11127-006-9104-2. 


\section{DETERMINANTS OF THE ELECTORAL CHANCES OF RURAL COMMUNE HEADS AND TOWN} MAYORS RUNNING FOR RE-ELECTION IN 2014

Abstract: The aim of the analysis was to determine the influence of quantifiable characteristics of candidates and communes (independent variables) on the electoral chances of rural commune heads and town mayors in the competitive election carried out at the prescribed time in 2014 (the dependent variable). It was assumed that the chances of re-election of rural commune heads and town mayors in the 2014 election were determined by a set of selected 15 explanatory variables such as: the duration of holding the office before, having the majority in the communal council after the previous election, or the asset-related investment expenditure per capita in the year of the election. The independent variables mostly come from public statistics sources (e.g., Central Statistical Office, National Electoral Commission) and are selected on the basis of source literature and conclusions from the field study. Logistic regression was performed on a study sample selected out of all communes except towns with poviat rights (with a balanced proportion of electoral failures and successes in 2014) in order to verify the assumptions. The results of the analysis suggest i.a., that the chance of re-election in 2014 was higher in the case of: holding the office since 2010 and not longer, having the majority in the communal council established in the previous election, or higher investment expenditure in the year of the election. On the other hand, the chance of re-election was lower in the case of higher electoral competition or higher proportion of expenditure for social welfare in the general expenditure of the commune in the year of the election.

Keywords: rural commune head, town mayor, determinants of re-election, 2014 election

\section{BIOGRAM}

Sławomir Bartnicki, dr, adiunkt w Instytucie Socjologii i Kognitywistyki Uniwersytetu w Białymstoku. Zainteresowania badawcze: samorząd terytorialny i socjologia organizacji. Kontakt e-mail: s.bartnicki@uwb.edu.pl. 


\section{ZAEĄCZNIK 1}

\section{CHARAKTERYSTYKA ZMIENNYCH NIEZALEŻNYCH}

\begin{tabular}{|c|c|c|c|c|}
\hline Skrót & Charakterystyka & Operacjonalizacja & Kierunek & Źródło \\
\hline kon & \# konkurentów & $\begin{array}{c}\text { n-1 kandydujących w } 2014 \text { roku } \\
\text { na stanowisko kierownika gminnej } \\
\text { egzekutyw }\end{array}$ & - & PKW \\
\hline staż & Staż inkumbenta & $\begin{array}{c}\text { Wybór w } 2010 \text { roku po raz } \mathrm{n}=1 \\
\text { wybór w } 2010 \text { roku po raz pierwszy } \\
=0\end{array}$ & - & PKW \\
\hline$w$ & $\begin{array}{c}\text { Większość formalna w radzie } \\
\text { gminy wg wyborów w } 2010 \\
\text { roku }\end{array}$ & $\begin{array}{c}\text { Posiadanie większości formalnej } \\
\text { w radzie gminy według wyborów } \\
\text { wyniku wyborów w } 2010 \text { roku }=1 \text {; } \\
\text { nie }=0\end{array}$ & + & JB \\
\hline typinc & $\begin{array}{l}\text { Typ komitetu wyborczego } \\
\text { inkumbenta w } 2014 \text { roku }\end{array}$ & $\begin{array}{c}\text { Komitet partii lub koalicji }=0 ; \text { komitet } \\
\text { wyborców lub organizacji }=1\end{array}$ & $\begin{array}{c}\text { brak } \\
\text { wpływu }\end{array}$ & PKW \\
\hline wmipc & $\begin{array}{c}\text { Wydatki majątkowe } \\
\text { inwestycyjne per capita } \\
\text { w } 2014 \text { roku }\end{array}$ & Zmienna ciągła logarytmizowana & + & GUS \\
\hline publW & \begin{tabular}{|} 
Dynamika odsetka podmiotów \\
sektora publicznego w masie \\
podmiotów gospodarki \\
narodowej ogółem w latach \\
$2011-2014$
\end{tabular} & $\begin{array}{l}\text { Zmienna ciągła szacowana: 1) jako } \\
\text { odsetek podmiotów publicznych } \\
\text { w masie podmiotów gosp. narodowej } \\
\text { ogółem; a następnie: } 2)(\text { n2014- } \\
\text { n2011)/n2011 x } 100\end{array}$ & + & GUS \\
\hline prac & \begin{tabular}{|c|} 
Liczba zatrudnionych na 1 tys. \\
ludności gminy w 2014 roku
\end{tabular} & Zmienna ciągła logarytmizowana & + & GUS \\
\hline$v m$ & $\begin{array}{c}\text { Odsetek wpisanych na } \\
\text { wniosek własny do rejestru } \\
\text { stałego wyborców w gminie } \\
\text { w IV kwartale } 2014 \text { roku } \\
\text { w stosunku do wpisanych } \\
\text { z urzędu w zakresie liter: a, b } \\
\text { i c Dz.U. } 2004 \mathrm{nr} 42 \text { poz. } 388 \\
\S 3 \text { ust. } 2 \text { pkt } 2 \\
\end{array}$ & $\begin{array}{c}\text { Zmienna ciągła logarytmizowana po } \\
\text { dodaniu do jej wartości bezwzględnej: } \\
0,01 \text { dlatego że w jednej z gmin } \\
\text { populacji generalnej odsetek ten } \\
\text { wynosił } 0\end{array}$ & - & PKW \\
\hline dynK & $\begin{array}{l}\text { Dynamika odsetka ludności } \\
\text { gminy z dostępem do sieci } \\
\text { kanalizacyjnej w latach } \\
\text { 2011-2014 } \\
\end{array}$ & $\begin{array}{l}\text { Zmienna ciągła szacowana: } \\
(\mathrm{n} 2014-\mathrm{n} 2011) / \mathrm{n} 2011 \times 100\end{array}$ & + & GUS \\
\hline kids & \begin{tabular}{|c|} 
Dynamika odsetka dzieci \\
w wieku 3-6 lat objętych \\
wychowaniem przedszkolnym \\
w latach 2011-2013
\end{tabular} & $\begin{array}{l}\text { Zmienna ciągła szacowana: } \\
(\mathrm{n} 2013-\mathrm{n} 2011) / \mathrm{n} 2011 \times 100\end{array}$ & + & GUS \\
\hline fso & \begin{tabular}{|c|} 
Fundacje, stowarzyszenia, \\
organizacje społeczne bez OSP \\
na 10 tys. ludności w 2014 \\
roku
\end{tabular} & Zmienna ciągła logarytmizowana & + & MP \\
\hline pom & \begin{tabular}{|c|} 
Wydatki gmin na pomoc \\
społeczną jako \% ogółu \\
wydatków gmin w 2014 roku
\end{tabular} & Zmienna ciągła logarytmizowana & - & MP \\
\hline
\end{tabular}




\begin{tabular}{|c|c|c|c|c|}
\hline Skrót & Charakterystyka & Operacjonalizacja & Kierunek & Źródło \\
\hline osp & $\begin{array}{c}\text { Ochotnicze straże pożarne na } \\
10 \text { tys. ludności w 2014 roku }\end{array}$ & Zmienna ciągła logarytmizowana & + & MP \\
\hline ludmed & Ludność gminy na 31.12.2014 & $\begin{array}{c}\text { Predyktor binarny }(<=7622 \\
\text { oznaczone jako: 0; }>7622 \text { oznaczone } \\
\text { jako: } 1)\end{array}$ & - & GUS \\
\hline lud & Ludność gminy na 31.12.2014 & & & GUS \\
\hline
\end{tabular}

Źródło: Opracowanie własne na podst.: GUS, PKW, (MP) MojaPolis, (JB) dane udostępnione przez Jerzego Bartkowskiego.

ZAŁĄCZNIK 2

STATYSTYKI OPISOWE ZMIENNYCH Z POPULACJI GENERALNEJ, N = 1931

\begin{tabular}{|c|c|c|c|c|c|c|}
\hline & Min. & Maks. & SD & $\mathrm{Av}$ & Mediana & $\mathrm{N}$ \\
\hline reelekcja $w 2014($ tak $=1 ;$ nie $=0)$ & 0 & 1 & 0,46 & 0,69 & 1 & 1931 \\
\hline kon & 1 & 10 & 1,35 & 2,33 & 2 & 1931 \\
\hline$s t a \dot{z}$ & 0 & 1 & 0,46 & 0,68 & 1 & 1931 \\
\hline$w$ & 0 & 1 & 0,49 & 0,47 & 0 & 1907 \\
\hline typinc & 0 & 1 & 0,37 & 0,83 & 1 & 1931 \\
\hline$v m+0,01$ & 0,01 & 11,57 & 1,09 & 1,07 & 0,7 & 1931 \\
\hline$v m+0,01$ (log) & $-4,61$ & 2,45 & 0,87 & $-0,31$ & $-0,34$ & 1931 \\
\hline prac & 15,92 & 1094,46 & 92,26 & 130,01 & 99,74 & 1931 \\
\hline prac (log) & 2,77 & 7 & 0,61 & 4,67 & 4,6 & 1931 \\
\hline$f_{S O}$ & 1,17 & 92,7 & 8,99 & 18,46 & 17,26 & 1921 \\
\hline fso (log) & 0,16 & 4,53 & 0,52 & 2,79 & 2,58 & 1921 \\
\hline wmipc & 8,41 & 12017,02 & 527,25 & 624,58 & 518,17 & 1931 \\
\hline wmipc (log) & 2,13 & 9,39 & 0,68 & 6,22 & 6,25 & 1931 \\
\hline publW & $-5,87$ & 4,13 & 0,63 & $-0,26$ & $-0,2$ & 1931 \\
\hline kids & -73 & 60,9 & 8,96 & 5,36 & 4,3 & 1931 \\
\hline$d y n K$ & $-14,1$ & 95 & 9,76 & 7,55 & 4 & 1931 \\
\hline pom & 2,21 & 44,73 & 4,48 & 15,81 & 15,57 & 1931 \\
\hline pom(log) & 0,79 & 3,8 & 0,31 & 2,71 & 2,74 & 1931 \\
\hline osp & 0,13 & 51,81 & 6,8 & 9,44 & 8,26 & 1899 \\
\hline osp (log) & $-2,01$ & 3,95 & 0,99 & 1,89 & 2,11 & 1899 \\
\hline $\begin{array}{l}\text { ludmed (ludność gminy (31.12.2014: } \\
<=7526 \text { to } 0 ;>7526 \text { to } 1)\end{array}$ & 0 & 1 & 0,5 & 0,5 & 1 & 1931 \\
\hline ludnossć gminy (31.12.2014) & 1335 & 78180 & 10330,9 & 11116,76 & 7526 & 1931 \\
\hline
\end{tabular}

Źródło: Obliczenia własne na podst.: PKW, GUS, MojaPolis (MP) i danych udostępnionych przez Jerzego Bartkowskiego (JB). Obok wartości statystyk opisowych zmiennych ciągłych logarytmizowanych są raportowane również wartości tych zmiennych w postaci bezwzględnej. 
ZAŁĄCZNIK 3

STATYSTYKI OPISOWE ZMIENNYCH Z PRÓBY ZBILANSOWANEJ, N=1211

\begin{tabular}{|c|c|c|c|c|c|c|}
\hline & Min. & Maks. & SD & Av & Mediana & $\mathrm{N}$ \\
\hline $\begin{array}{l}\text { reelekcja } w 2014 \\
(\text { tak }=1 ; \text { nie }=0)\end{array}$ & 0 & 1 & 0,5 & 0,5 & 1 & 1211 \\
\hline kon & 1 & 10 & 1,44 & 2,51 & 2 & 1211 \\
\hline staż & 0 & 1 & 0,46 & 0,69 & 1 & 1211 \\
\hline$w$ & 0 & 1 & 0,49 & 0,43 & 0 & 1196 \\
\hline typinc & 0 & 1 & 0,36 & 0,84 & 1 & 1211 \\
\hline$v m+0,01$ & 0,05 & 11,57 & 1,09 & 1,07 & 0,72 & 1211 \\
\hline$v m+0,01(\log )$ & -3 & 2,45 & 0,84 & $-0,29$ & $-0,32$ & 1211 \\
\hline prac & 15,92 & 1094,46 & 97,50 & 132,65 & 101,27 & 1211 \\
\hline prac (log) & 2,77 & 7 & 0,62 & 4,68 & 4,61 & 1211 \\
\hline fso & 1,17 & 78,91 & 9,16 & 18,74 & 17,43 & 1206 \\
\hline fso (log) & 0,16 & 4,37 & 0,52 & 2,8 & 2,85 & 1206 \\
\hline wmipc & 8,41 & 12017,02 & 536,05 & 607,58 & 500,5 & 1211 \\
\hline wmipc (log) & 2,13 & 9,39 & 0,69 & 6,17 & 6,21 & 1211 \\
\hline publW & $-5,87$ & 3,64 & 0,58 & $-0,25$ & $-0,2$ & 1211 \\
\hline kids & $-44,1$ & 51,5 & 8,72 & 5,14 & 4,2 & 1211 \\
\hline dynK & $-10,6$ & 68,6 & 9,35 & 7,25 & 3,8 & 1211 \\
\hline pom & 2,57 & 34,28 & 4,37 & 15,94 & 15,73 & 1211 \\
\hline pom(log) & 0,94 & 3,53 & 0,3 & 2,72 & 2,75 & 1211 \\
\hline$o s p$ & 0,13 & 38,21 & 6,73 & 9,31 & 8,07 & 1193 \\
\hline $\operatorname{osp}(\log )$ & $-2,01$ & 3,64 & 1,01 & 1,86 & 2,08 & 1193 \\
\hline $\begin{array}{l}\text { ludmed (ludność gminy } \\
\text { (31.12.2014: }<=7526 \text { to } 0 ;> \\
7526 \text { to } 1 \text { ) }\end{array}$ & 0 & 1 & 0,5 & 0,5 & 1 & 1211 \\
\hline ludność gminy (31.12.2014) & 1335 & 74333 & 10715,9 & 11454,68 & 7622 & 1211 \\
\hline
\end{tabular}

Źródło: Obliczenia własne na podst.: PKW, GUS, MojaPolis (MP) i danych udostępnionych przez Jerzego Bartkowskiego (JB). Obok wartości statystyk opisowych zmiennych ciągłych logarytmizowanych są raportowane również wartości tych zmiennych w postaci bezwzględnej. 